\title{
Effect of Pulsed Electric Current Treatment on Corrosion of Structural Metals
}

\author{
A. I. Babutskii, ${ }^{\text {A A. Chrysanthou, }{ }^{\text {b }} \text { and J. Ioannoub }}$ \\ ${ }^{a}$ Pisarenko Institute of Problems of Strength, National Academy of Sciences of Ukraine, \\ Kiev, Ukraine \\ ${ }^{b}$ School of Aerospace, Automotive and Design Engineering, University of Hertfordshire, \\ Hatfield, UK
}

УДК $620.193 ; 537.39$

\section{Влияние обработки импульсным электрическим током на коррозию металлических конструкционных материалов}

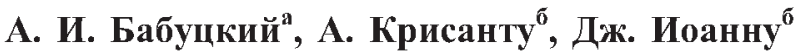 \\ ${ }^{a}$ Институт проблем прочности им. Г. С. Писаренко НАН Украины, Киев, Украина \\ ${ }^{\sigma}$ Школа аэрокосмического, автомобильного машиностроения и дизайна, Хертфорд- \\ ширский университет, Хатфильд, Великобритания
}

Представленьл результатьл испьтаний на коррозию ряда конструкиионньлх материалов, предварительно подвергаемьх воздействио импульсного электрического пока высокой плотности. Установлено, что такая обработка существенно влияет на коррозию исследуемьх материалов. Для стали НSLA и алюминиевого сплава 5182 происходит рост сопротивления коррозии, в то время как для алюминиевого сплава 5754 - резкое уменьшение сопротивления коррозии.

Ключевые слова: коррозия, импульсный электрический ток, сталь, алюминиевый сплав.

Introduction. The problem of corrosion of structural metals remains critical because it is connected with considerable economic costs. According to various estimations, 10 to $30 \%$ of the annual production of iron is irreversibly lost due to corrosion every year [1]. Corrosion leads not only to loss of metal, but also to degradation of mechanical and physical properties and plasticity. This is the reason for the decrease in the lifetime of components sometimes leading to catastrophic failure. For example, $90 \%$ of failures in oil-field pipes take place due to corrosion damages; a similar situation occurs in ships [2, 3] and other structures. Taking into account the repair-and-renewal operations and anticorrosion measures, the losses from corrosion in highly developed countries reach up to $10 \%$ of the national income [1].

The existing methods of metal and alloy protection from corrosion include deposition of coatings, electrochemical methods of protection (e.g., cathodic method) and others. It is therefore understandable that there is considerable interest to develop new and more effective corrosion protection methods. 
One of the common types of metal and alloy corrosion is electrochemical corrosion, which leads to damage in conductive environments (electrolytic solutions). In general, the electrochemical corrosion mechanism involves the appearance of short-circuited micro-galvanic elements on the metal surface with different values of e.m.f. as a result of the formation of anodic (with low electrode potential) and cathodic (with high electrode potential) zones [4]. These zones are generated due to differences in metal structure, surface roughness, as well as existence of protective films and other factors. The difference in metal structure (difference of grain size and composition, crystal anisotropy, emergence of dislocations on the surface, existence of impurities, inclusions, nonuniform mechanical stresses) is one of the reasons activating corrosion processes. The role of mechanical stresses is important because anode zones can appear under the influence of tensile stresses in the metal. These zones become the source of development of corrosion centres [5].

It is known that pulsed electric current (PEC) treatment causes relaxation of mechanical stresses in metals [6-8], as well as homogenization of their structure [9]. Based upon common considerations, these circumstances can serve as a basis for the creation of new technology of corrosion protection of metals. The results of investigations below were fulfilled with the aim to clarify the mentioned possibilities.

Method of Experimental Research. Metallic sheet specimens of high-strength low-alloy steel (HSLA of composition $0.02 \% \mathrm{C}, 0.25 \% \mathrm{Mn}, 0.02 \% \mathrm{~S}, 0.02 \% \mathrm{P}$, $0.30 \% \mathrm{Ti}$ ) of $100 \mathrm{~mm}$ length, $13 \mathrm{~mm}$ width and $1.1 \mathrm{~mm}$ thickness and aluminum alloy $5182(4.5 \% \mathrm{Mg}, 0.3 \% \mathrm{Mn})$ of $100 \mathrm{~mm}$ length, $13 \mathrm{~mm}$ thickness and $1.4 \mathrm{~mm}$ thickness and $5754(3.6 \% \mathrm{Mg}, 0.5 \% \mathrm{Mn}, 0.1 \% \mathrm{Cu}, 0.4 \% \mathrm{Fe}, 0.4 \% \mathrm{Si}$ ) of $100 \mathrm{~mm}$ length, $13 \mathrm{~mm}$ width and $2 \mathrm{~mm}$ thickness were used for the investigation.

Corrosion tests were performed at $35^{\circ} \mathrm{C}\left( \pm 1.5^{\circ} \mathrm{C}\right)$ in a salt-spray chamber (Fig. 1) using a $5 \% \mathrm{NaCl}$ solution (in distilled water) according to the ASTM B117-97 standard. The total time of exposure was 1000 hours. The treatment was carried out in hourly cycles. This involved subjecting the specimens to a fog spray (salt spray) for 10 minutes at a flow rate of $0.71 / \mathrm{h}$ followed by 50 minutes of hot air drying. The sequence was repeated every hour.

The specimens were initially cleaned under hot water by hand. They were further cleaned in an ultrasonic chamber with water of $48^{\circ} \mathrm{C}$, for 12 minutes; this process occurred twice because the replacement of the water was necessary. They were then washed with propanol and dried for $30 \mathrm{~min}$ at $70^{\circ} \mathrm{C}$. The specimens were then weighed and placed in the corrosion salt-spray chamber. After the corrosion test the specimens were cleaned in hot water to remove deposits of salt. They were then washed with propanol and dried at $70^{\circ} \mathrm{C}$ in an oven. They were subsequently weighed.

PEC treatment of the specimens was performed using a pulsed current generator [10]. Three electric current pulses were passed through each specimen with current amplitude as indicated in Table 1. The amplitude of the electric current was chosen with the aim to compare the specimens with the same current density taking into account their different thickness (approximately 1.3, 2.0, and $3.0 \mathrm{kA} / \mathrm{mm}^{2}$, respectively, for each specimen group). 
$\mathrm{T}$ a $\mathrm{b} 1$ e 1

\section{Regimes of PEC Treatment}

\begin{tabular}{|c|c|c|c|}
\hline \multirow{2}{*}{ No. } & Steel HSLA & Aluminum alloy 5182 & Aluminum alloy 5754 \\
\cline { 2 - 4 } & \multicolumn{3}{|c|}{ Current amplitude, kA } \\
\hline 1 & 19 & 24 & 34 \\
2 & 19 & 24 & 34 \\
3 & 29 & 35 & 53 \\
4 & 29 & 35 & 53 \\
5 & 41 & 52 & 75 \\
6 & 41 & 52 & 75 \\
\hline
\end{tabular}

Note. Specimens Nos. 1, 3, and 5 were treated using three pulses with 1 min interval, specimens Nos. 2, 4, and 6 were treated using three pulses with 3 min interval.

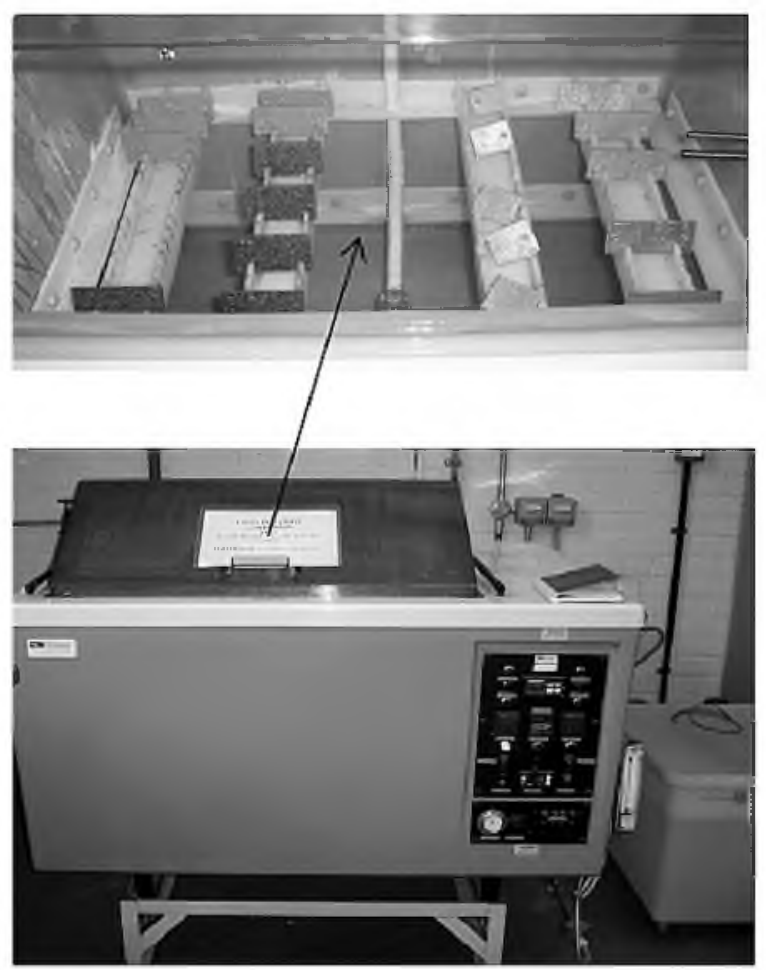

Fig. 1. Equipment for corrosion tests.

Test Results and Their Analysis. Test results are presented in Table 2 and Figs. 2 and 3. In comparative analysis of test results, one should take account of the different corrosion behavior of steel and aluminum alloys; in the case of steel, the corrosion products $\left(\mathrm{Fe}_{2} \mathrm{O}_{3}\right.$ oxides) flake off the base material, which causes the reduction of specimen weight after the corrosion tests, while in the case of aluminum alloys the increase of specimen weight is observed after corrosion tests because $\mathrm{Al}_{2} \mathrm{O}_{3}$ oxides have high adhesion to the base material.

The estimation of the PEC treatment effect on corrosion of specimens was performed in two steps. The percentage change of the weight of each specimen $\delta_{m}$ after tests was estimated in the first stage: 
$\mathrm{T}$ a b 1 e 2

\section{Results of Corrosion Tests}

\begin{tabular}{|c|c|c|c|c|c|c|}
\hline \multirow[t]{3}{*}{ No. } & \multicolumn{2}{|c|}{ Steel HSLA } & \multicolumn{2}{|c|}{ Aluminum alloy 5182} & \multicolumn{2}{|c|}{ Aluminum alloy 5754} \\
\hline & \multicolumn{6}{|c|}{ After PEC treatment } \\
\hline & $\delta_{m}, \%$ & $k, \%$ & $\delta_{m}, \%$ & $k, \%$ & $\delta_{m}, \%$ & $k, \%$ \\
\hline 1 & -0.5224 & 26 & 0.1217 & 15 & 0.2695 & -491 \\
\hline 2 & -0.5310 & 25 & 0.1571 & -9 & 0.3112 & -582 \\
\hline 3 & -0.2706 & 62 & 0.1188 & 17 & 0.4200 & -821 \\
\hline 4 & -0.6010 & 15 & 0.0614 & 57 & 0.4655 & -921 \\
\hline 5 & -0.6890 & 2 & 0.1640 & -14 & 0.2976 & -553 \\
\hline \multirow[t]{2}{*}{6} & -1.2729 & -81 & 0.1426 & 1 & 0.3120 & -585 \\
\hline & \multicolumn{6}{|c|}{ Without PEC treatment } \\
\hline \multirow{2}{*}{$\begin{array}{c}\text { Mean } \\
\text { for } 6 \text { specimens }\end{array}$} & \multicolumn{2}{|c|}{$\delta_{m}, \%$} & \multicolumn{2}{|c|}{$\delta_{m}, \%$} & \multicolumn{2}{|c|}{$\delta_{m}, \%$} \\
\hline & \multicolumn{2}{|c|}{-0.7050} & \multicolumn{2}{|c|}{0.1437} & \multicolumn{2}{|c|}{0.0456} \\
\hline
\end{tabular}

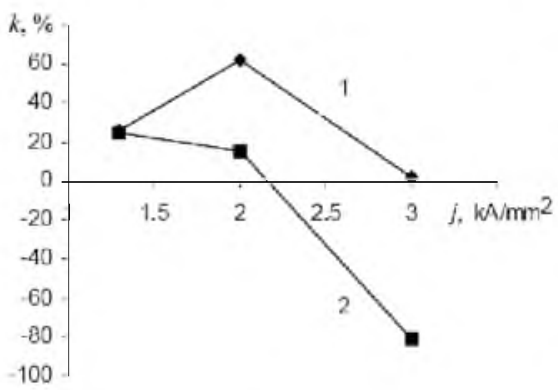

$a$

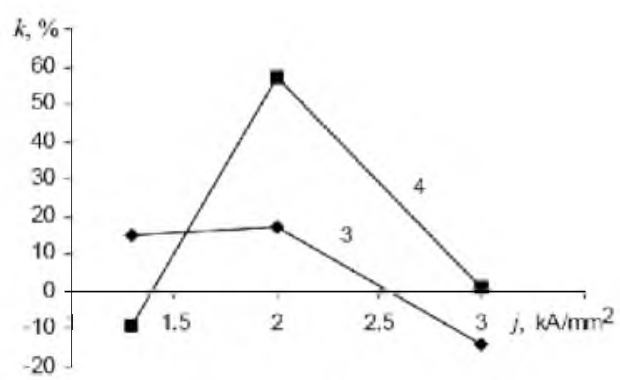

$b$

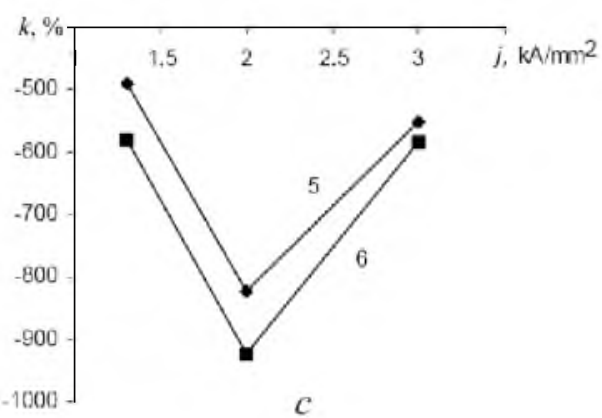

Fig. 2. Variation of factor of PEC treatment effect on specimen corrosion $(k)$ for different materials [(a) HSLA steel, (b) 5182 aluminum alloy, (c) 5754 aluminum alloy], PEC densities, and intervals between electric current pulses [(1), (3), (5) 1 min interval; (2), (4), (6) 3 min interval].

$$
\delta_{m}=\frac{m_{c}-m_{0}}{m_{0}} \cdot 100 \%,
$$

where $m_{0}$ and $m_{c}$ are the weights of the initial specimen and the same specimen after the corrosion tests, respectively. In the second stage, the factor of PEC treatment effect on the specimen corrosion, $k$, was determined as follows: 


$$
k=\frac{\left|\delta_{m}^{\text {untreat }}\right|-\left|\delta_{m}^{\text {treat }}\right|}{\left|\delta_{m}^{\text {untreat }}\right|} \cdot 100 \%,
$$

where $\delta_{m}^{\text {untreat }}$ is the percentage change of the weight of untreated specimens (mean for 6 specimens bottom row in Table 2) and $\delta_{m}^{\text {treat }}$ is the percentage change of the weight of each specimen treated by PEC (Table 2).

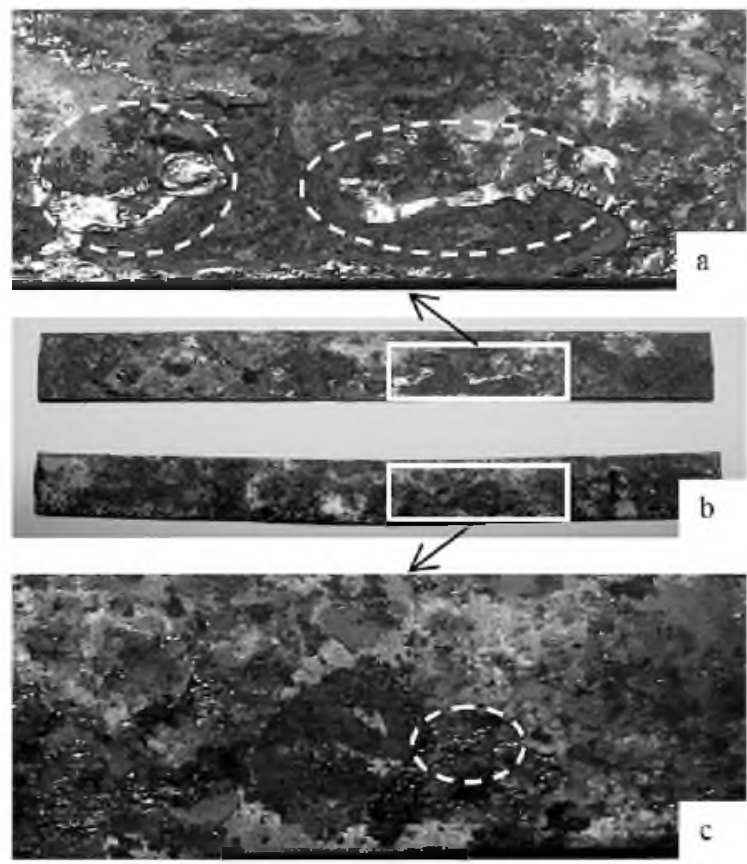

Fig. 3. Surface appearances of HSLA steel specimens after corrosion tests: $(a),(b$ : top photo) metal in initial condition; ( $b$ : bottom photo), $(c)$ after PEC treatment.

The corrosion tests results suggest that the PEC treatment using the above regimes substantially affects the behavior of the investigated metals. The treatment causes considerable deceleration of the corrosion processes for both HSLA steel and 5182 aluminum alloy. Here, the results obtained indicate that regimes of PEC treatment with maximum effect exist. On the other hand, for 5754 aluminum alloy, the treatment using the same regimes (current densities) dramatically impairs (in times) its resistance to corrosion.

Macrophotographs of the surface appearance of the investigated HSLA steel specimens after the corrosion tests are presented in Fig. 3 (the difference in the appearance of treated and untreated specimens in case of aluminum alloy specimens is insignificant). A substantial difference in the corrosion damage of surfaces of PEC-treated and untreated HSLA steel specimens is observed. In the case of the specimens without PEC treatment, zones with selective, localized corrosion are visibly clear (areas bordered by dash lines in Fig. 3a). PEC treatment causes uniform, homogeneous corrosion on the whole surface of specimen (see, for example, area bordered by dash line in Fig. 3c). This observation may be to be due to different structural and surface heterogeniety of the treated and untreated 
specimens. Such heterogeinity may arise during sheet manifacturing process by means of cold working, which generates nonuniform residual stresses. On the other hand, the PEC treatment may relieve these stresses, thus providing a more homogeneous material.

Conclusions. The results of this investigation have shown that PEC treatment has a significant effect on the corrosion behavior of structural metals. Based on these observations, the following conclusions can be drawn:

(i) the regimes of PEC treatment used in this work cause an increase of corrosion resistance of HSLA steel and 5182 aluminum alloy, but at the same time they cause dramatic decrease of the corrosion resistance of 5754 aluminum alloy;

(ii) as a result of the PEC treatment, the corrosion on the surface of the HSLA steel specimens becomes weaker and more homogenous; the zones of localized corrosion observed in the case of the untreated specimens are absent on the surface of the PEC-treated HSLA steel specimens.

The investigation performed was based on one specimen per variant of PEC treatment. Further research will be carried out using more specimens, in order to accumulate experimental data on the effect of PEC treatment with different parameters on the corrosion characteristics of structural metals, as well as to study the sources and physical mechanisms of such phenomena in metals.

\section{Резиме}

Наведено результати випробувань на корозію ряду конструкційних матеріалів, що попередньо зазнавали впливу імпульсного електричного струму високої густини. Установлено, що така обробка суттєво впливає на корозію матеріалів. Для сталі HSLA й алюмінієвого сплаву 5182 має місце зростання опору корозії, в той час як для алюмінієвого сплаву 5754 - різке зменшення опору корозіі.

1. E. M. Gutman, K. R. Nizamov, M. D. Getmanskii, and E. A. Nizamov, Corrosion Protection of Oil-Field Equipment [in Russian], Nedra, Moscow (1983).

2. H. Emi, A. Kumano, N. Baba, et al., "A study on life assessment of ships and offshore structures. Pt. 1: Basic study," J. Soc. Nav. Archit. Jpn., No. 169, 443-454 (1991).

3. H. Emi, M. Yuasa, A. Kumano, et al., "A study on life assessment of ships and offshore structures. Pt. 3: Corrosion control and condition evaluation for a long life service of the ship," J. Soc. Nav. Archit. Jpn., No. 174, 735-744 (1993).

4. N. I. Isaev, Theory of Corrosion Processes [in Russian], Metallurgiya, Moscow (1997).

5. http://www.cathedral.ru/cathedra/num2/demidov.

6. Yu. V. Baranov, O. A. Troitskii, Yu. S. Avraamov, and A. D. Shlyapin, Physical Bases of Electro-Impulse and Electro-Plastic Treatments and New Materials [in Russian], MGIU, Moscow (2001). 
7. G. V. Stepanov, A. I. Babutsky, and L. Krushka, "Metal behavior under passage of pulse electric current," J. Phys. IV France, 110, 577-582 (2003).

8. G. V. Stepanov, A. I. Babutsky, and G. V. Chyzhyk, "Estimation of pulse electric current effect on strength of metallic materials," Metaloznav. Obrob. Metal., No. 2, 64-68 (2005).

9. G. V. Stepanov, A. I. Babutskii, and I. A. Mameev, "High-density pulse current-induced unsteady stress-strain state in a long rod," Strength Mater., 36, No. 4, 377-381 (2004). 